\title{
AVALIAÇÃO DAS ÁREAS DE PRESERVAÇÃO PERMANENTE NA BACIA DO CÓRREGO OLHOS D'ÁGUA, UBERLÂNDIA/MG, SEGUNDO A LEGISLAÇÃO CONCERNENTE
}

\author{
Fernanda Oliveira Borges $^{(\mathrm{a})}$, Paula Souza Queiroz ${ }^{(\mathrm{b})}$ \\ (a) Instituto de Geografia, Universidade Federal de Uberlândia, fborges242@gmail.com \\ (b) Instituto de Geografia, Universidade Federal de Uberlândia; paula.sq@ @otmail.com
}

Eixo: Uso e ocupação das terras e legislação ambiental

\begin{abstract}
Resumo
Áreas de Preservação Permanente (APP) correspondem à vegetação que delimita as margens de um curso hídrico e possuem a função de protege-lo de possíveis intervenções que possam ser prejudiciais à qualidade do meio, garantindo a conservação da biodiversidade e manutenção do ecossistema. No Brasil, a preocupação com as APPs só veio a acontecer com a aplicação da Lei 4.771/65, voltando a ser reforçada em 2012 com o Novo Código Florestal Brasileiro, com a Lei 12.651/12. O intuito do trabalho é avaliar as APPs da bacia do córrego Olhos D’Água, localizada no município de Uberlândia, Minas Gerais, verificando sua conformidade com a legislação vigente, utilizando recursos de geoprocessamento. Alcançando o objetivo do trabalho, identificou-se áreas em que o uso da terra por atividades antrópicas está em conflito com as APPs, ou seja, ocupando áreas que deveriam ser de preservação permanente.
\end{abstract}

Palavras chave: Áreas de preservação; Curso hídrico; Lei 12.651/12; Uso da terra; Conflitos.

\section{Introdução}

A problemática ambiental vem sendo discutida há tempos, porém, o que está gerando maior preocupação no momento é o uso desordenado e desenfreado dos recursos hídricos. Observa-se alto consumo gerado pelas grandes demandas, desperdícios e níveis de poluição que tem se agravado continuamente no decorrer da ininterrupta apropriação capitalista do espaço. Neste sentido, os modelos de gestão da água incorporaram o conceito de sustentabilidade. Por tal razão, a gestão ambiental e da água passaram a ter grande importância nas políticas públicas e de desenvolvimento de vários países.

A partir da Lei 9.433/1997, foram estabelecidos planos de recursos hídricos e instituído o Sistema Nacional de Gerenciamento de Recursos Hídricos com os objetivos de: coordenar a gestão integrada das águas; implementar a Política Nacional de Recursos Hídricos; planejar, regular e controlar o uso, a preservação e a recuperação dos recursos hídricos; entre outros. Uma das formas de preservação destes recursos é a manutenção das Áreas de Preservação Permanente (APP), protegidas por lei, garantindo, da mesma forma, o equilíbrio ecodinâmico da paisagem, a conservação da fauna, da flora e a qualidade de vida socioambiental.

O Código Florestal Brasileiro, instituído em 1965 regido pela Lei 4.771/65, trouxe pela primeira vez em seus escritos a necessidade de recomposição ou preservação de 30 (trinta) metros de mata ciliar para 
rios com até 10 (dez) metros de largura. As metragens mínimas de proteção dos cursos hídricos através das APPs foram mantidas e reformadas com a aplicação do Novo Código Florestal Brasileiro, sob a Lei 12.651/12, dispondo também sobre 50 (cinquenta) metros de vegetação nativa no entorno das nascentes.

Por conseguinte, tem-se como objetivo a avaliação das Áreas de Preservação Permanente na Bacia do córrego Olhos D’Água, por meio da utilização de técnicas de geoprocessamento, de modo a verificar quais são as áreas de preservação ideais de acordo com a legislação concernente e, assim, considerar como se dá o uso da terra na área de estudo, identificando áreas de conflito.

\section{Materiais e Métodos}

Para a elaboração do conteúdo teórico do trabalho houve levantamento bibliográfico, em literatura capaz de consolidar as discussões, como em leis e códigos brasileiros que respondem a algumas das implicações aqui mencionadas e trabalhadas.

Com fins de construção das representações temáticas, os mapas, utilizou-se das bases cartográficas do IBGE, 1989, Carta Topográfica Ilha do Funil, Folha SE-22-Z-B-VI-4-SE, e Carta Topográfica Cachoeira do Sucupira, Folha SE-22-Z-B-VI-4-SO, ambas obtidas no Laboratório de Cartografia da Universidade Federal de Uberlândia. Todas as manipulações foram realizadas com o auxílio das ferramentas do Sistema de Informações Geográficas - SIG ArcGIS 10.1, disponibilizado pelo Laboratório de Ensino de Geotecnologias da mesma unidade acadêmica mencionada. O trabalho de campo foi essencial para a captura de informações e imagens acerca da área, permitindo uma aproximação entre pesquisador e pesquisado.

Para a elaboração do mapa de uso da terra, utilizou-se de uma imagem de satélite obtida no Google Earth Pro, do ano de 2015, que foi georreferenciada no SIG. Foram definidas seis classes de uso, de acordo com as particularidades da área e, posteriormente, fez-se a vetorização manual de cada classe com base na imagem de satélite.

De modo a definir as APPs utilizou-se Brasil (2012), que define 30 (trinta) metros dessas áreas para cursos d'água com até 10 (dez) metros de largura, realidade que se aplica ao córrego estudado, e 50 (cinquenta) metros para áreas de reservatórios, lagos, lagoas e nascentes. Com base nestas definições, utilizou-se a ferramenta buffer (que determina a área de influência de um objeto), na delimitação do curso hídrico, de acordo com os valores indicados, demonstrando as áreas ideais nas quais deveriam conter as APPs.

Para obter a representação dos conflitos de uso do solo, fez-se um cruzamento entre as informações das APPs (ideais) e o uso da terra, onde seu resultado apresenta as áreas que deveriam possuir a vegetação natural de proteção ao curso d'água, segundo as determinações da lei, porém estão sendo ocupadas por atividades de uso antrópico. 
XVII Simpósio Brasileiro

de Geografia Fisica Aplicada

I Congresso Nacional

de Geografia Física

\section{OS DESAFIOS DA GEOGRAFIA FÍSICA NA FRONTEIRA DO CONHECIMENTO \\ Instituto de Geociências - Unicamp \\ Campinas - SP \\ 28 de Junho à 02 de Julho de 2017}

\section{Caracterização da área}

A Bacia Hidrográfica do córrego Olhos D’Água está localizada às margens da BR-365 (Uberlândia Montes Claros) no KM 19, entre as Coordenadas Geográficas: -18.904394, -18.920482 de Latitude e48.121522, -48.174864 de Longitude, estando a lés-nordeste da cidade de Uberlândia, conforme representado na Figura 1.

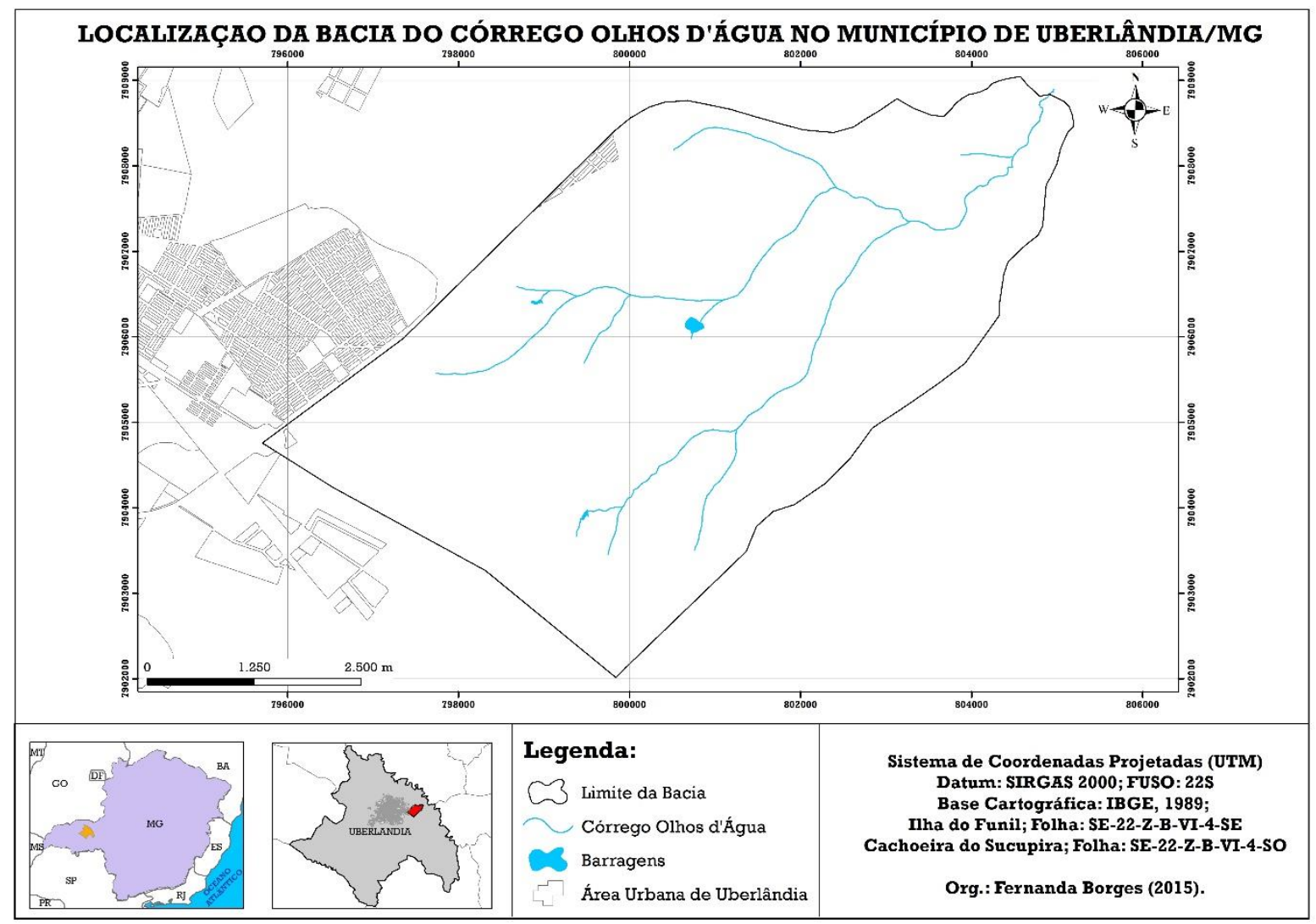

Figura 1 - Localização da bacia do Córrego Olhos d'Água. Fonte: Organizado por: BORGES, F.O.; 2015.

O topo da bacia do córrego Olhos D’Água possui uma geologia caracterizada pelos arenitos da Formação Marília do Grupo Bauru, enquanto que no fundo de vale há o afloramento do basalto da Formação Serra Geral do Grupo São Bento, formando diversas quedas d'água, corredeiras e cachoeiras.

Segundo Oliveira et. al. (2009), no encontro dos córregos Olhos D'água e Três Marcos, onde o curso passa a se chamar Córrego Boa Vista, a geologia é representada pelos gnaisses e micaxistos do Grupo Araxá. Ainda segundo as autoras a geomorfologia na nascente da área de estudo é caracterizada, através das denominações de Baccaro (1994), como Áreas de Relevo de Topo Plano, característicos de relevos suaves e com baixas declividades. O médio e baixo curso desses córregos está na unidade geomorfológica denominada Área de Relevo Intensamente Dissecado, identificado por vales encaixados, entalhando o basalto e as rochas do Grupo Araxá. 
Quanto à vegetação, devido ao fato da área de estudo ter uma ocupação secular, boa parte de sua vegetação nativa já foi alterada, entretanto ainda é possível identificar manchas de Cerrado Stricto Sensu, veredas e Matas galeria. O primeiro tipo é mais característico de árvores tortuosas de médio e pequeno porte, compostos por cascas grossas e foi praticamente extinto nessa região. O segundo tipo é abundante nas nascentes, e é um tipo de vegetação associada a solos hidromórficos, geralmente em áreas planas ou em vales, acompanhando linhas de drenagem mal definidas. As matas de galeria existentes sofrem com a ação do homem, mas ainda resistem em certas áreas, sendo um tipo de vegetação que acompanha o curso hídrico.

Segundo Borges \& Queiroz (2014) a área de estudo está localizada sob a área de influência da zona tropical, tendo um clima caracterizado por duas estações bem definidas, uma seca (maio/setembro) e outra úmida (outubro/abril), caracterizando invernos secos e verões chuvosos, com temperaturas variando de $19^{\circ} \mathrm{C}$ à $27^{\circ} \mathrm{C}$, com uma média mensal se $22,3^{\circ} \mathrm{C}$ e pluviosidade média em torno de 1500 $\mathrm{mm}$ por ano.

\section{Legislação concernente}

A mata ciliar é a vegetação presente nas margens de corpos d'água, como rios, córregos e lagos, incluindo suas superfícies de inundação. Essa vegetação é ecologicamente muito importante para os cursos d'água e bacias hidrográficas na medida em que colabora com a manutenção da qualidade da água, com o desenvolvimento e sobrevivência da fauna silvestre aquática ou terrestre, com a estabilidade dos solos, evitando erosão e assoreamento, além de desempenhar muitas outras funções, como a manutenção do equilíbrio ecossistêmico.

Dessa forma, é fundamental a permanência das matas ciliares como Áreas de Preservação Permanente (APP), conforme estabelecido pelo Novo Código Florestal Brasileiro, instituído pela lei $\mathrm{n}^{\circ} 12.651$, de 25 de maio de 2012. Além das matas ciliares, a lei também considera como Áreas de Preservação Permanente os manguezais, as restingas, encostas com declividade superior a $45^{\circ}$, bordas de tabuleiros ou chapadas, topos de morros, montes, montanhas e serras, as veredas, áreas no entorno de nascentes, entre outras. O Novo Código Florestal define APP como:

área protegida, coberta ou não por vegetação nativa, com a função ambiental de preservar os recursos hídricos, a paisagem, a estabilidade geológica e a biodiversidade, facilitar o fluxo gênico de fauna e flora, proteger o solo e assegurar o bem-estar das populações humanas (BRASIL, 2012).

Conforme ainda afirmam Sevilha et al., (2006), a conservação e preservação das APPs é regulada por um conjunto de normas permeado por conflitos em função das diferentes restrições de uso impostas por legislações distintas - Código Florestal (1965), Resoluções CONAMA 302, 303 (2002), Lei Lehman (1979) e regulamentações específicas de uso e ocupação do solo municipais. 
XVII Simpósio Brasileiro

de Geografia Fisica Aplicada

I Congresso Nacional

de Geografia Física

\section{OS DESAFIOS DA GEOGRAFIA FÍSICA NA FRONTEIRA DO CONHECIMENTO \\ Instituto de Geociências - Unicamp \\ Campinas - SP \\ 28 de Junho à 02 de Julho de 2017}

Com relação à delimitação das APPs na área de estudo, as faixas no entorno dos cursos d'água devem ter largura mínima de 30 (trinta) metros, contados a partir da borda da calha do leito regular, pois os cursos d'água têm largura inferior a $10(\mathrm{dez})$ metros. Ao redor das nascentes e olhos d'água perenes, as APPs devem ter raio de, no mínimo, 50 (cinquenta) metros, o que vale também para as superfícies de inundação, ou seja, as barragens e afins, conforme apresentado na Figura 2.

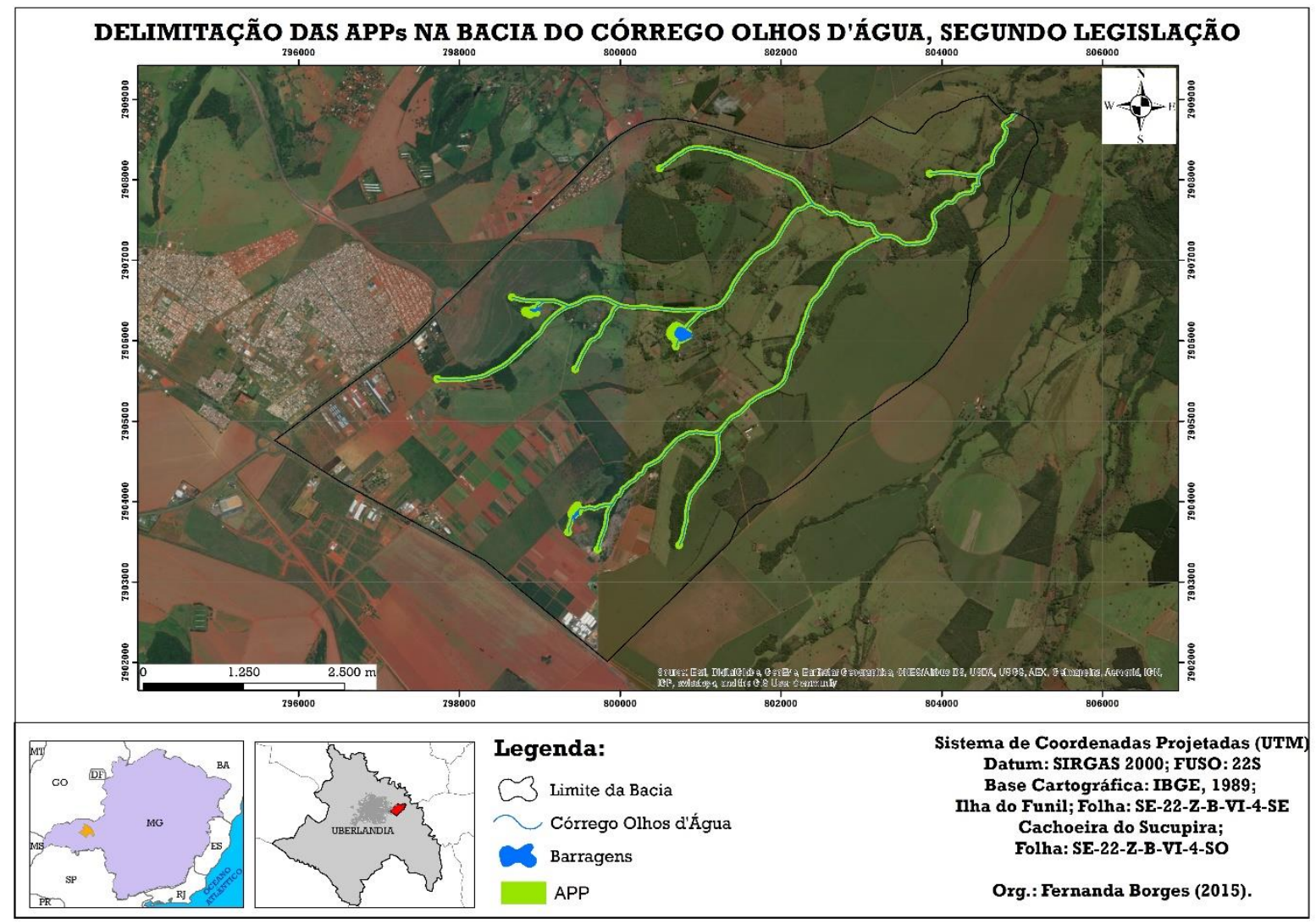

Figura 2 - APPs segundo o Código Florestal Brasileiro. Fonte: Organizado por: BORGES, F.O.; 2015.

Em casos de supressão da vegetação situada em APP, o proprietário da área é obrigado a recompor a vegetação, exceto em casos de atividades agrossilvipastoris, de ecoturismo e de turismo rural em áreas rurais consolidadas até 22 de julho de 2008, sendo, nestes casos, permitida a continuidade das atividades. A intervenção ou supressão de vegetação nativa em Área de Preservação Permanente é permitida apenas em casos de utilidade pública, de interesse social ou de baixo impacto ambiental previstos na lei. $\mathrm{O}$ acesso de pessoas e animais em APP é permitido para obtenção de água e realização de atividades de baixo impacto ambiental.

Mesmo em casos de áreas consolidadas, quando é permitida a continuidade das atividades realizadas em APP, é obrigatória a recomposição de uma parcela da vegetação nativa no entorno de cursos d'água naturais, sendo, no mínimo, de 5 (cinco) metros de largura para imóveis de até 1 (um) módulo fiscal; 8 (oito) metros para imóveis de 1 (um) a 2 (dois) módulos fiscais; 15 (quinze) metros para imóveis de 2 (dois) a 4 (quatro) módulos fiscais; e 20 (vinte) metros para imóveis com área superior a 4 (quatro) 
módulos fiscais. Também no entorno de nascentes e olhos d'água perenes que tenham atividades consolidadas em APP, é obrigatória a recomposição da vegetação nativa em um raio mínimo de 15 (quinze) metros.

\section{O Uso da Terra e seus conflitos em APPs na Bacia Hidrográfica do córrego Olhos D’Água}

Estudos do uso e ocupação da terra têm se tornado uma ferramenta de suma importância no planejamento e gestão de microbacias, com foco na manutenção e melhor uso dos recursos e o aproveitamento das áreas de uso. Entende-se que um bom aproveitamento das áreas de uso implica na não destruição das APPs em torno dessas microbacias. Em contrapartida, o uso inadequado do solo gera perdas significativas ao meio ambiente e aumento de áreas conflitivas.

Assim, nos dizeres de Amato \& Sugamosto (2000), o planejamento do uso da terra de acordo com as exigências vigentes na legislação é um processo essencial, que visa à conservação dos recursos naturais. Outrossim, a demarcação geográfica das áreas de preservação permanente (APP) destacadas pela lei e a confrontação desses locais com o seu uso atual, determinam as medidas a serem adotadas com o objetivo de contribuir com o uso racional das terras.

Acredita-se que o uso adequado da terra é o primeiro passo em direção a uma agricultura correta. Logo, cada parcela de terra deve ser utilizada de acordo com a sua capacidade de sustentação e produtividade econômica, de forma que os recursos naturais sejam colocados à disposição do homem para melhor uso e benefício, procurando ao mesmo tempo preservar estes recursos para gerações futuras (LEPSCH et al., 1991).

Referente à tipologia de uso da terra na área da bacia em estudo, percebe-se que, a pastagem aparece como a forma mais difundida. Não obstante, e em consonância com os objetivos deste trabalho, elaborou-se a Tabela I com a porcentagem de cada tipologia de uso e a Figura 3, afim de melhor ilustrar e situar a distribuição no uso da terra na área da bacia.

Tabela I - Representação das áreas ocupadas por tipo de uso em relação à área total. Fonte: Organizada pelos autores, 2015.

\begin{tabular}{ll}
\hline TIPO DE USO & ÁREA OCUPADA EM \% \\
\hline Vegetação Natural & $18 \%$ \\
Indústria/Agroindústria & $4 \%$ \\
Solo Exposto & $10 \%$ \\
Equipamentos Urbanos & $1 \%$ \\
Pastagem & $61 \%$ \\
Agricultura & $6 \%$ \\
\hline Área Total & $\mathbf{1 0 0 \%}$ \\
\hline
\end{tabular}




\section{OS DESAFIOS DA GEOGRAFIA FÍSICA NA FRONTEIRA DO CONHECIMENTO Instituto de Geociências - Unicamp \\ Campinas - SP \\ 28 de Junho à 02 de Julho de 2017}

Nota-se que a bacia é majoritariamente ocupada com o uso na forma de pastagem, (61\% do total). Os demais usos dizem respeito à vegetação natural, solo exposto, agricultura, indústria/agroindústria e equipamentos urbanos, com 18\%, 10\%, 6\%, 4\%, e 1\%, respectivamente. Perante tais números, percebese que a bacia possui poucos equipamentos urbanos e áreas industriais, que estão restritas a algumas indústrias e um pequeno bairro situados à borda da bacia.

Ao se tratar da agricultura, salienta-se que o período da tomada da imagem orbital pode gerar dificuldade na interpretação de culturas, assim como da ocorrência de solo exposto estar comumente correlacionado com a presença de algum tipo de cultivo. Considerando-se o período da tomada da imagem, nota-se que o uso da terra voltado para o uso na agricultura exerce pouca expressão da área da bacia, e que a presença de solo exposto atingiu quatro pontos percentuais a mais que a área momentaneamente cultivada.

Por fim, analisa-se a ocorrência de vegetação nativa, a qual totalizou 18\%, indicando que, a princípio, embora a bacia esteja sendo utilizada para diversas finalidades, há o cuidado com áreas de preservação permanente e reserva legal. Entretanto, parte dessas áreas está sendo utilizada de maneira incorreta, sobretudo o uso conflituoso existente com a pastagem, tópico que, doravante, será abordado.

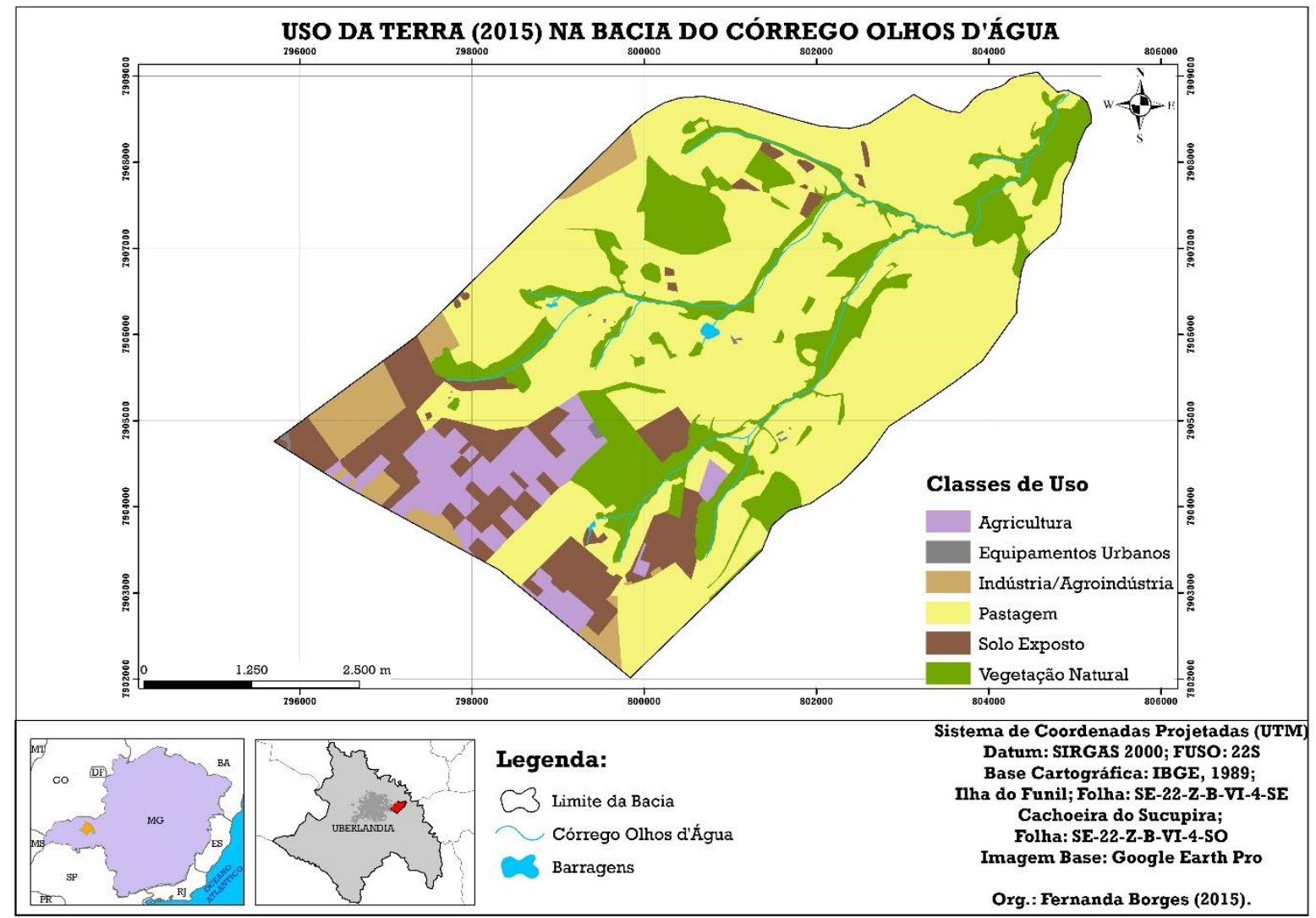

Figura 3 - Representação do uso e ocupação do solo com predominância de pastagens. Fonte: GOOGLE EARTH, 2014; Organizado por: BORGES, F.O.; 2015.

Os conflitos de uso são determinados pelas ocupações inadequadas da terra dentro de Áreas de Preservação Permanente. Os usos caracterizados por pastagens, reflorestamento e solo exposto são 


\section{OS DESAFIOS DA GEOGRAFIA FÍSICA NA FRONTEIRA DO CONHECIMENTO \\ Instituto de Geociências - Unicamp \\ Campinas - SP \\ 28 de Junho à 02 de Julho de 2017}

considerados conflitos dentro de áreas de preservação permanente, sendo as matas e várzeas consideradas parte natural destas últimas.

Conforme Madruga et al. (1999) destacou, muitas áreas são ocupadas inadequadamente devido a planejamentos precários, falta de informações e de um estudo adequado. O levantamento de uso da terra é de fundamental importância na medida em que os efeitos do uso desordenado causam deterioração no ambiente. Este mal-uso é denominado conflito de uso da terra. De acordo com Rocha (1991) estes conflitos ocorrem quando as culturas agrícolas são desenvolvidas em áreas impróprias ou áreas apropriadas que possuem declividades inadequadas aos padrões conservacionistas.

Determinadas ações como desmatamentos para implantação de agroindústrias, de mineradoras, para a criação de animais, plantações e muitas outras atividades ligadas ao uso e cobertura da terra, se constituem como um dos grandes desafios para as políticas de controle ambientais (ARAÚJO et al., 2009). A necessidade de identificar e compreender as formas de apropriação dos espaços físicos e as vertentes sociais, políticas e econômicas que as potencializam merecem destaque frente aos objetivos atuais de conservação ambiental e desenvolvimento sustentável.

No que se refere ao uso da terra, dentro do debate do desenvolvimento sustentável, a representação temática inserida em contextos históricos de desenvolvimento podem se tornar alternativas efetivas na investigação dos fatores que levam as mudanças nos padrões de ocupação dos espaços geográficos (NORA et al., 2009).

Nota-se que grande parte das áreas de APP referente à área da Bacia do córrego Olhos D'água está sendo utilizada de maneira irregular, com destaque para o uso na forma de pastagem com percentual de 55\%. A utilização de pastagens em áreas de APP apresenta-se de maneira recorrente no cenário agrícola nacional em razão de diversas ocasiões, chamando-se atenção para os recentes "acordos" políticos realizados mediante o Novo Código Florestal.

A Tabela II evidencia o percentual de ocupação em conflito de cada classe de uso, dentro da área que deveria ser APP em conformidade com a legislação vigente. Parte das áreas ocupadas irregularmente por pastagem também está vinculada às áreas destinadas a serem utilizadas como parte da reserva legal da propriedade rural. Percebe-se também a presença de solo exposto em uma área de nascente situada ao sul da bacia em questão, sendo responsável por $2 \%$ da área de conflito na bacia.

Tabela II - Representação em \% da área conflitante por tipo de uso do solo em relação à área total. Fonte: Organizada pelos autores, 2015.

\begin{tabular}{ll}
\hline TIPO DE USO & ÁREA EM CONFLITO EM \% \\
\hline Vegetação Natural & $43 \%$ \\
Solo Exposto & $2 \%$ \\
Pastagem & $55 \%$ \\
\hline Área Total & $\mathbf{1 0 0 \%}$ \\
\hline
\end{tabular}




\section{OS DESAFIOS DA GEOGRAFIA FÍSICA NA FRONTEIRA DO CONHECIMENTO \\ Instituto de Geociências - Unicamp \\ Campinas - SP \\ 28 de Junho à 02 de Julho de 2017}

A Figura 4 ilustra as áreas de conflitos na Bacia do córrego Olhos D’água, mediante sobreposição das áreas de APP com as diversas formas de uso e ocupação da terra pertinentes à bacia.

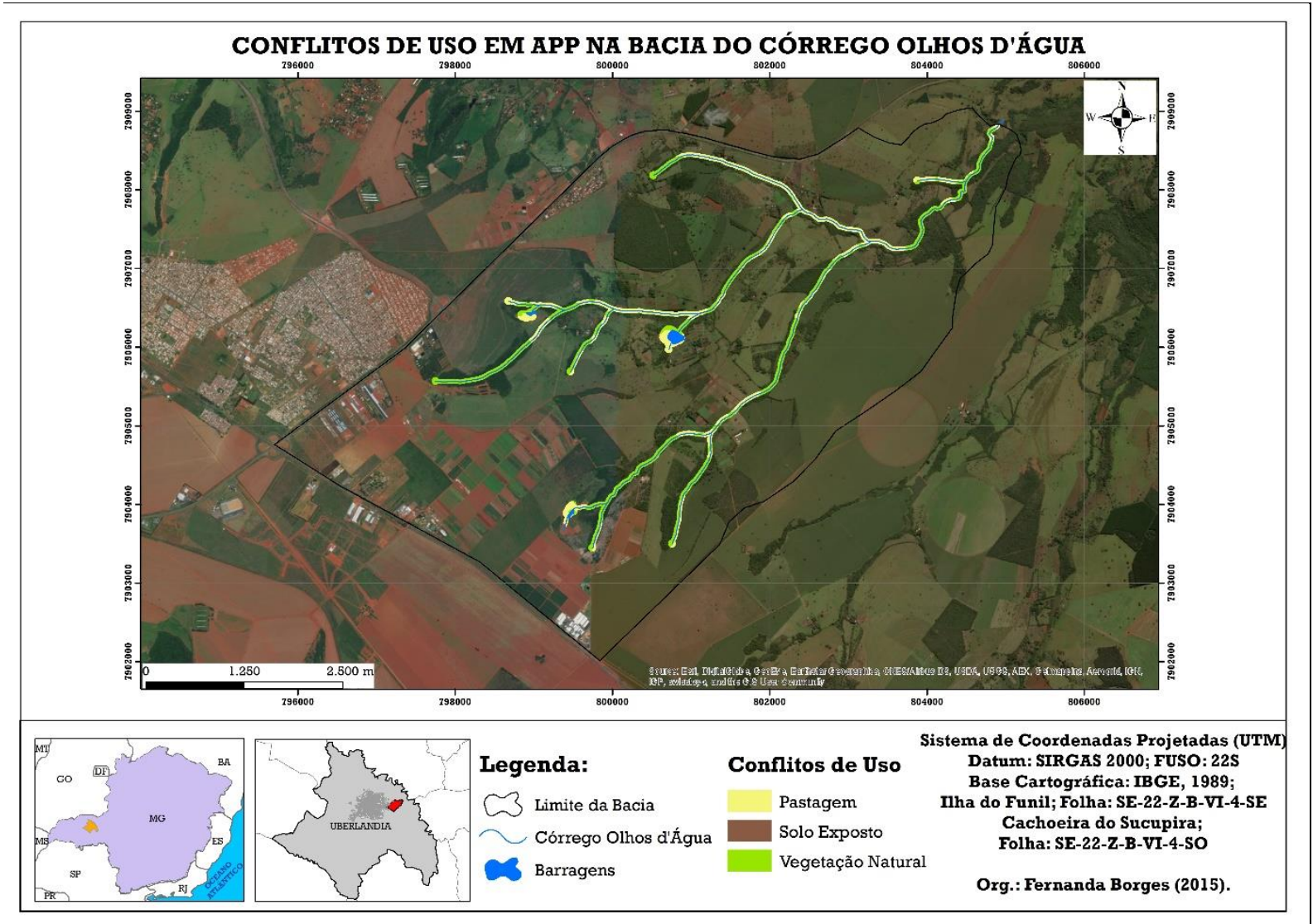

Figura 4 - Regiões conflitantes em APP. Fonte: Organizado por: BORGES, F.O.; 2015.

Ademais, as áreas de represamento de águas superficiais estão dentre as áreas conflituosas na bacia com ocorrência de pelo menos três represas, apresentando alguma irregularidade com relação ao respeito da distância necessária da margem de seus leitos.

\section{Considerações Finais}

As Áreas de Preservação Permanente (APP) são de fundamental importância para o ambiente e a sociedade, uma vez que colaboram para a melhoria da qualidade de vida das pessoas e contribui para a preservação dos solos e dos recursos hídricos, evitando erosão das margens e assoreamento dos cursos d'água, além de serem áreas de refúgio para a fauna e a flora, funcionando como corredores ecológicos e sendo, muitas vezes, os últimos fragmentos de vegetação nativa.

No caso da Bacia Hidrográfica do córrego Olhos D’Água, a situação das APPs está longe do cenário considerado ideal pela legislação brasileira. As áreas delimitadas pela legislação como de APP às margens do córrego, nascentes, olhos d'água e barragens, são utilizadas também para outros fins que não a preservação da vegetação nativa. O principal uso conflitante nas APPs ideais, delimitadas através 
de técnicas de geoprocessamento, é o uso por pastagens que, no cruzamento das informações, representa uma ocupação de mais que a metade da área que deveria ser de APP. É importante ressaltar que muitas, ou todas essas áreas ocupadas por outros usos, podem ser áreas de uso já consolidado, o que é previsto na legislação, porém mesmo sendo áreas consolidadas é preciso recuperar uma porcentagem da vegetação nativa para se adequarem à lei e permitirem, minimamente, que as APPs cumpram seu papel ecológico.

Para que seja possível a preservação dessas áreas, é de extrema importância a conscientização da população através da divulgação de informações, por meio de auxílio técnico para sua efetivação e de fiscalização, pois muitas pessoas utilizam essas áreas de APP apenas porque desconhecem a legislação e os impactos que podem causar. Dentro deste contexto, as universidades podem contribuir de muitas formas, através de pesquisas e projetos de educação ambiental e de assistência técnica.

\section{Bibliografia}

AMATO, F., SUGAMOSTO, M. L. Sistemas de Informações Geográficas no controle de desmatamento irregular na Área de Proteção Ambiental de Guaraqueçaba e de ocupação antrópica no entorno do Parque Nacional de Superagüi [CD-ROM]. In: GISBRASIL 2000, Salvador, 2000, Anais... Fatorgis - Informação e Eventos Tecnológicos.

ARAÚJO, E. P.; TELES, M. G. L.; LAGO, W. J. S. Delimitação das bacias hidrográficas da Ilha do Maranhão a partir de dados SRTM. In: SIMPÓSIO BRASILEIRO DE SENSORIAMENTO REMOTO, XIV, 2009, Natal. Anais... Natal: 2009. p. 4631-4638.

BACCARO, C. A. D. As Unidades Geomorfológicas e a Erosão nos Chapadões do Município de Uberlândia. Uberlândia: Sociedade e Natureza, v. 6, Uberlândia, 1994. p. 19-33.

BORGES, F. O.; QUEIROZ, P. S. Possíveis medidas de controle e recuperação da feição erosiva da Bacia do Rio Araguari-MG. Uberlândia: III Simpósio Internacional Saúde Ambiental para as cidades, 2014, 10 p.

BRAGA, R.; CARVALHO, P. F. Recursos hídricos e planejamento urbano e regional. Rio Claro: Laboratório de Planejamento Municipal - Deplan - UNESP - IGCE, 2003, 131 p.

BRASIL. Constituição (1965). BRASIL. Constituição (1965). Lei no 4771, de 15 de setembro de 1965. Institui o Código Florestal. Lei. Brasília, 1965.

BRASIL. Constituição (1997). Lei $\mathrm{n}^{\circ}$ 9433, de 8 de janeiro de 1997. Institui a Política Nacional de Recursos Hídricos, cria o Sistema Nacional de Gerenciamento de Recursos Hídricos, regulamenta o inciso XIX do art. 21 da Constituição Federal, e altera o art. $1^{\circ}$ da Lei ${ }^{\circ}$ 8.001, de 13 de março de 1990, que modificou a Lei n $^{\circ} 7.990$, de 28 de dezembro de 1989.. Lei. Brasília, 1997.

BRASIL. Constituição (2012). Lei no 12651, de 25 de maio de 2012. Dispõe sobre a proteção da vegetação nativa; altera as Leis nos 6.938, de 31 de agosto de 1981, 9.393, de 19 de dezembro de 1996, e 11.428, de 22 de dezembro de 2006; revoga as Leis nos 4.771, de 15 de setembro de 1965, e 7.754, de 14 de abril de 1989, e a Medida Provisória no 2.166-67, de 24 de agosto de 2001; e dá outras providências.. Lei. Brasília, 2012.

CARVALHO, R. G. de. As bacias hidrográficas enquanto unidades de planejamento e zoneamento ambiental no Brasil. Presidente Prudente: Caderno Prudentino de Geografia, n. 36, Volume Especial, 2014, p. 26-43.

LEPSCH, J. F. et al. Manual para levantamento utilitário do meio físico e classificação de terras no sistema de capacidade de uso. Campinas, Soc. Bras. Cien. do Solo, 1991. 175 p.

MADRUGA, P. R. A.; GARCIA, S. M.; CORSEUIL, C. W.; KURTZ, F.C., SANTINI, N. L.; ZANON, P. C. F.; PERCORARO A. J.; LIMA, R. R. Uso do sistema de informação geográfica Idrisi na determinação dos conflitos de uso do solo em uma microbacia pertencente à subbacia Arroio Grande (RS). In: CONGRESSO BRASILEIRO DE ENGENHARIA AGRÍCOLA, 28, 1999, Pelotas. Anais em CD ROM... Pelotas-RS, 1999. 
NORA, E. L. D.; MOREIRA, M. A.; SANTOS,C.;A. Análise da dinâmica de usos e ocupação da terra no Município de Maravilha - SC através de imagens de satélite e geoprocessamento. In: SIMPÓSIO BRASILEIRO DE SENSORIAMENTO REMOTO, XIV, 2009, Natal. Anais... Natal: 2009. p.5725-573.

OLIVEIRA, H. L. de P. R.; SOARES, Ângela Maria; MELO, C. S.. Bacia Hidrográfica do Córrego Olhos d’Água - Uberlândia -MG: um estudo da área. Uberlândia. Faculdade Católica, 2009.

ROCHA, J. S. M. Manual de manejo integrado de bacias hidrográficas. ed. UFSM, Santa Maria, RS. 1991. $181 \mathrm{p}$.

SANTOS, R. F. dos. Área, escala e tempo: paradigmas do planejamento. In: Planejamento Ambiental: teoria e prática. São Paulo: Oficina de Textos, 2004, p. 39-70.

SCHIAVETTI, A.; CAMARGO, A. F. M. Conceitos de Bacias Hidrográficas: teorias e aplicações. Ilhéus: Editus, 2005, 293 p.

SEVILHA, E. R.; DEMANTOVA, G. C.; FREIRIA, R. C. Conflitos na Proteção Legal das Áreas de preservação permanentes urbanas. In: I Seminário do Laboratório de Fluxos - FEC/UNICAMP, 2006.

SILVA, Emerson Malvino da. O clima na cidade de Uberlândia-MG. Sociedade \& Natureza, Uberlândia, v. 16, n., p. 91-107, 15 abr. 2004. 